\title{
Estimating gillnet selectivity of Bluefish (Pomatomus saltatrix) by morphology
}

\section{Lüferin (Pomatomus saltatrix) morfolojisiyle galsama ağı seçiciliğinin tahmini}

\author{
Akın Türker İlkyaz \\ Ege University, Faculty of Fisheries, 35100, Bornova, Izmir, Turkey \\ ilkyaza@gmail.com
}

How to cite this paper:

Illkyaz A.T. (2018). Estimating gillnet selectivity of Bluefish (Pomatomus saltatrix) by morphology. Ege Journal of Fisheries and Aquatic Sciences, 35(1): 89-94. doi:10.12714/egejfas.2018.35.1.14

\begin{abstract}
The dataset of the study consists of total length, fork length, head girth, maximum girth and weight measurements of 136 bluefish. The relationship between the total length and fork length of the product was $T L=1.1348 \times F L-0.8184$; the relationship between the total length and weight was $W=0.0103 \times L^{2.97}$. The relationships between the total length and head girth and between the total length and maximum girth of the sample were linear: the relationship of the total length and head girth was $G_{\text {gill }}=0.5092 \times T L-0.0874$; the relationship of the total length and maximum girth was $G_{\max }=0.5989 \times T L-0.8540$. The statistical relationship between length and girth was used to obtain a theoretical gillnet selectivity equation for the species. In conclusion, a relationship of $S(I)=\Phi\left[\left(C-G_{\text {gill }} / 0.4952\right] \times\left[1-\Phi\left(\left(C-G_{\max }\right) / 0.4255\right)\right]\right.$ was determined between the stretched size of the mesh used in bluefish fishing and the catch rate. Using this equation, and considering the legal length and length at first maturity, the minimum mesh size of the gillnet for sustainable fishery was determined.
\end{abstract}

Keywords: Direct estimation, Sechin method, length-girth relationship, length-length relationship, length-weight relationship

Öz: Çalışmanın veri setini, 136 adet lüfer balığı üzerinde yapılan; total boy, çatal boy, operkulum çevresi, vücut çevresi ve ağırlık ölçümleri oluşturmaktadır. Türün total boyu ile çatal boyu arasında $T L=1,1348 \times F L-0,8184$, total boyu ile ağırlığı arasında ise $W=0,0103 \times L^{2,97}$ şeklinde bir ilişki olduğu tespit edilmiştir. Örnekleme ait total boy-operkulum çevresi ve total boy-vücut çevresi arasında ise sırası ile $G_{\text {gill }}=0,5092 \times T L-0,0874$ ve $G_{\text {max }}=0,5989 \times T L-0,8540$ şeklinde doğrusal bir ilişkinin olduğu hesaplanmıştır. Boy ile çevre arasında kurulan istatistiksel ilişkiler kullanılarak, türe ait kuramsal uzatma ağı seçicilik denklemi elde edilmiştir. Sonuç olarak, türün avcılığında kullanılabilecek ağın tam göz boyu ile yakalanma oranları arasında $S(I)=\Phi\left[\left(C-G_{\text {gill }} / 0,4952\right] \times\left[1-\Phi\left(\left(C-G_{\text {max }}\right) / 0,4255\right)\right]\right.$ şeklinde bir ilişkinin olduğu tespit edilmiştir. Elde edilen bu denklemden faydalanılarak, türün yasal ve ilk üreme boyları dikkate alınarak, sürdürülebilir bir avcılık için kullanılacak sade uzatma ağının minimum tam göz boyunun ne olması gerektiği belirlenmiştir.

Anahtar kelimeler: Direkt tahmin, Sechin metodu, boy-çevre ilişkisi, boy-boy ilişkisi, boy-ağırlık ilişkisi

\section{INTRODUCTION}

Bluefish (Pomatomus saltatrix Lin., 1766), the only member of the Pomatomidae family (Whitehead et al., 1986), is a rapidly migrating, pelagic and predatory species (Haimovici and Krug, 1996). Their distribution extends to a wide area including the Atlantic, Pacific and Indian Oceans, and they inhabit the continental shelves of warm and temperate seas (Wilk, 1977). They have a high commercial value around the world (Froese and Pauly, 2016). In Turkey, in addition to gillnets and hooks (Hoşsucu, 2000), they are also caught with purse seine and trawl. According to the statistics from the General Fisheries Commission for the Mediterranean (GFCM), the average fish production of Turkey in the last decade was 7,252.8 $\pm 1,355.6$ tons and the majority of the production was from the Black Sea and the Marmara Sea $(\bar{x} \pm$ SE) $(F A O, 2016)$.
The bluefish is a symbol for various non-governmental organizations committed to preserving marine life in Turkey; it is used in many campaigns regarding this issue. Discussions on its legal catch length have always reached an impasse and as a natural consequence of these long-lasting discussions, the legal length has undergone many changes: The first legal length was determined to be $15 \mathrm{~cm}$ fork length (FL) during the fishing season in 1986-1987; over time, the legal length reached $18 \mathrm{~cm}(\mathrm{FL})$ and $20 \mathrm{~cm}(\mathrm{TL})$. Until today, the lowest legal length was $14 \mathrm{~cm}(\mathrm{TL})$ during the 11-year long fishing season beginning in 2000; no length ban was implemented during the 1999-2000 fishing season. The length ban for the current fishing season is $18 \mathrm{~cm}$ total length (Anonymous, 2016). 
In Turkey, in addition to its high economic value, bluefish is historically and traditionally highly valued. Few species that are similarly valued are also given names based on their lengths: bluefish are named "defneyaprağı" (<10 cm), "çinekop" (10-20 $\mathrm{cm})$, "sarıkanat" $(20-25 \mathrm{~cm})$, "kofana" $(35-40 \mathrm{~cm})$ and "sırtıkara" (>40 cm TL) (Deveciyan, 1915; Türgan, 1959).

In this study, the theoretical catch rate of gillnet was determined by utilizing the morphological structure of bluefish, and by considering this rate mesh sizes of gillnet for fishing above the legal length and length at first maturity were calculated.

\section{MATERIALS AND METHODS}

The material of the study consists of morphological measurements obtained from 136 bluefish. The samples were collected from different fishing gears (line and net fishing) intended for sampling with large length range. Total length (TL), fork length $(F L)$, head girth $\left(G_{\text {gill }}\right)$ and maximum girth $\left(G_{\max }\right)$ of individual fish were measured at $0.1 \mathrm{~mm}$ and the total body weight was recorded at $0.01 \mathrm{~g}$ sensitivity.

Linear regression was used to determine the relationships between total length and fork length (TL-FL), total length and head girth (TL- $\left.G_{\text {gill }}\right)$, and total length and maximum girth (TL$G_{\max }$ ) of the samples:

$y=b \times x+a$

In the equation, $x$ represents the independent variable, $y$ represents the dependent variable, $a$ and $b$ represent the regression intercept and slope. The relationship between length and weight of the species was calculated with:

$W=a \times L^{b}$

In the equation, $W$ represents the weight at each $L$ length, while $a$ and $b$ represent the regression coefficient (Ricker, 1973). The intercept and slope parameters of the relationships were estimated by linear regression analysis on logtransformed length and weight data.

Growth type of the species was determined using the Student's $t$-test. The power of the correlation between established relationships was determined with the determination coefficient $\left(R^{2}\right)$.

A theoretical selectivity model, which is based on the relationship between the fish length and girth, and is also known as the Sechin method, was used to estimate the selectivity parameters and selectivity curve (Sechin, 1969; Kawamura, 1972). This model is suited to species with a morphology that allows for gilled and wedged; and the model is based on determining two length groups ( $G_{\text {gill }} \leq C \leq G_{\max }$ );

a) Determination of length groups small enough to get their heads into the mesh,

b) Determination of length groups large enough to be retained by the mesh.

In the study, the equations that were modified from Sechin (1969) by Reis and Pawson (1999) by simplifying and applying the equations to commercial fishery data were adopted:

$$
\begin{aligned}
& P^{\text {retained }}=P\left\{G_{\max } \geq C\right\}=1-\Phi\left(\frac{C-G_{\max }}{\sigma_{\max }}\right) \\
& P^{\text {passing }}=P\left\{G_{\text {gill }} \leq C\right\}=\Phi\left(\frac{C-G_{\text {gill }}}{\sigma_{\text {gill }}}\right) \\
& S(l)=P^{\text {retained }} \times P^{\text {passing }}
\end{aligned}
$$

In the equations, $S$ represents the estimated catch rate at each I length, $C$ represents the mesh size (stretched mesh size×2), $G_{\max }$ and $G_{\text {gill }}$ represent the maximum girth and head girth for each / fish length; $\Phi$ represents the cumulative normal standard distribution function, $\sigma_{\text {gill }}$ and $\sigma_{\max }$ represent the standard deviation of the relationships between fish lengthhead girth and fish length-maximum girth. Using these equations, a normal distribution curve is obtained from two transverse sigmoid curves' combination. All calculations were carried out using MS-Excel $\circledast$ functions.

\section{RESULTS}

In the study, the total length of the smallest sample was $16.5 \mathrm{~cm}$, whereas the total length of the largest sample was $35.3 \mathrm{~cm}$. The average length of the samples was $23.25 \mathrm{~cm}$ and the standard error was $\pm 0.34 \mathrm{~cm}$. A relationship, $W=0.0103 \times L^{2.97} \quad\left(R^{2}=0.987\right)$ was determined between the weight and length of the species. At $95 \%$ confidence interval, standard error of $b$ (slope) value of this relationship was \pm 0.07 , and therefore the growth type of the species was determined to be isometric ( $t$-test). The linear and strong relationship between the fork length $(F L)$ and total length $(T L)$ of the samples was determined as $\mathrm{TL}=1.1348 \times \mathrm{FL}-0.8184\left(R^{2}=0.999\right)$.

A linear relationship, $G_{\max }=0.5989 \times T L-0.8540\left(R^{2}=0.968\right.$, $\left.\sigma_{\max }=0.4255\right)$ was determined between the total length and maximum girth of the bluefish. In addition, a linear relationship, $G_{\text {gill }}=0.5092 \times T L-0.0874 \quad\left(R^{2}=0.942, \quad \sigma_{\text {gill }}=0.4952\right) \quad$ was determined between the total length and head girth of the species (Figure 1). 


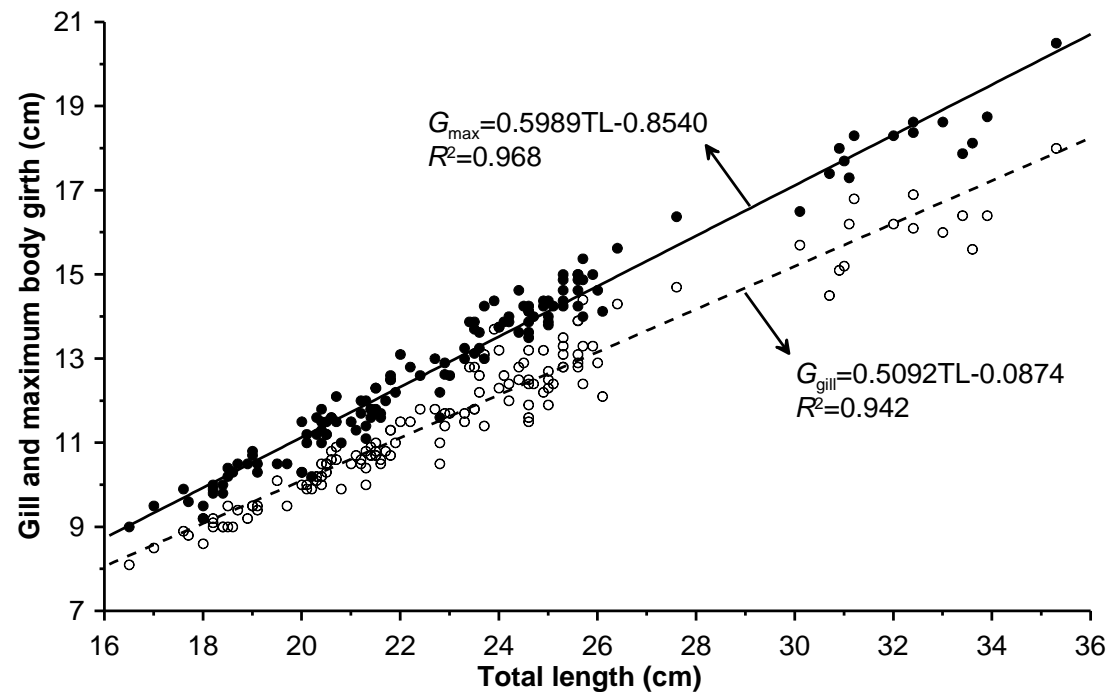

Figure 1. Total length-head girth and total length-maximum girth relationships of the bluefish (Pomatomus saltatrix) $(\bullet$ and I: TL-Gmax; $\circ$ and I: TL- $G_{\text {gill }}$.

The morphometric relationship between the length, head girth and maximum girth revealed the following relationship between the stretched mesh size and catch rate:

$S(l)=\Phi\left(\frac{C-(0.5092 \times \mathrm{TL}-0.0874)}{0.4952}\right) \times\left[1-\Phi\left(\frac{C-(0.5989 \times \mathrm{TL}-0.854)}{0.4255}\right)\right]$

This relationship showed that the stretched mesh size of the gillnet that allows for fishing above the $18 \mathrm{~cm}$ legal length was $55 \mathrm{~mm}$. This mesh size, the probability of catching individuals at $18 \mathrm{~cm}$ legal length was 6\%, optimum catch length was $20.75 \mathrm{~cm}$ total length and catch rate at optimum catch length was $77.8 \%$ (Figure 2).

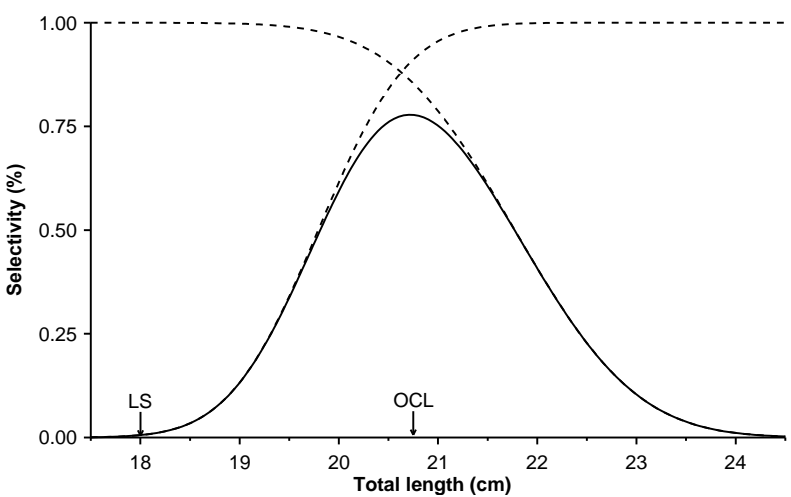

Figure 2. Estimated gillnet selectivity of $55 \mathrm{~mm}$ stretched mesh size for the bluefish (Pomatomus saltatrix) (LS: Legal size, OCL: Optimum catch length)

In Turkey, the length at first maturity was reported as 25.4 $\mathrm{cm}$ fork length (Ceyhan et al., 2007). Total length measurements are accepted as the main measurement standard in legal regulations; therefore, this value should be converted to total length for practical use. The relationship equation obtained in this study for total length and fork length revealed that the length at first maturity was $28.0 \mathrm{~cm}$ total length for bluefish. A gillnet with an $85 \mathrm{~mm}$ stretched mesh size allowed for fishing above the length at first maturity. Theoretically, with this mesh size, $5 \%$ of the individuals at first maturity length were caught, optimum catch length was 31.45 $\mathrm{cm}$ and the catch rate for individuals at optimum catch length was $97.5 \%$ (Figure 3 ).

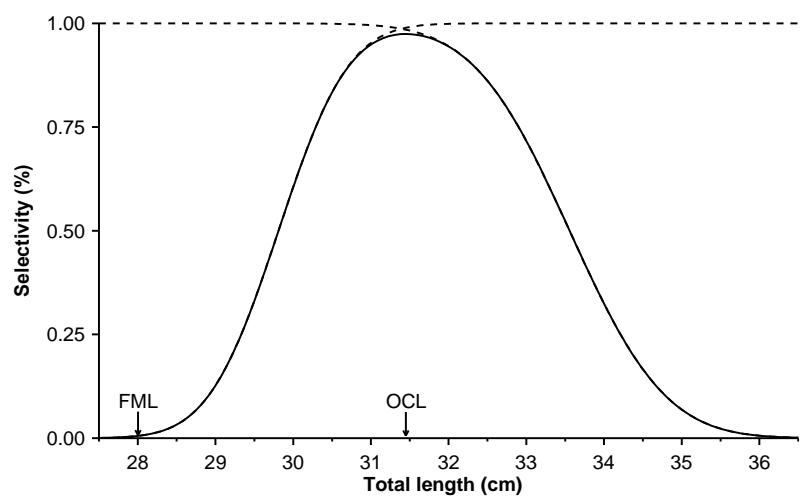

Figure 3. Estimated gillnet selectivity of $85 \mathrm{~mm}$ stretched mesh size for the bluefish (Pomatomus saltatrix) (FML: Length of first maturity, OCL: Optimum catch length)

\section{DISCUSSION}

The total length-fork length relationship established in this study was used to convert previous researchers' findings regarding fork length to the total length. Froese and Pauly (2016) reported that, based on the measurements of pictures of the species, the total length of the species was 1.0834 times the fork length. van der Elst (1976), for individuals inhabiting the South African coast, and Bal et al. (2015), for individuals sampled from the southern Marmara Sea, reported the relationship between the total length and fork length. The 
findings of our study were mostly similar to the findings of Froese and Pauly (2016) and Bal et al. (2015), whereas the findings of van der Elst (1976) were considerably different from all of these studies (Table 1).

Table 1. Total length-total weight and total length-fork length relationships of the present and previous studies for the bluefish (Pomatomus saltatrix)

\begin{tabular}{|c|c|c|c|c|}
\hline$L-W$ & GT & LR & $L-L$ & Study \\
\hline & & & $T L=1.0834 \times F L+0$ & Froese and Pauly, 2016 \\
\hline & & & $T L=1.306 \times F L+3.06$ & van der Elst, 1976 \\
\hline$W=0.0388 \times L^{2.56}$ & $-A$ & & & Erkoyuncu et al., 1994 \\
\hline$W=0.0130 \times L^{2.8621}$ & $-\mathrm{A}$ & $13.2-21.7$ & & Kalaycı et al., 2007 \\
\hline$W=0.0325 \times L^{2.527}$ & $-\mathrm{A}$ & $10.6-24.0$ & & Bök et al., 2011 \\
\hline$W=0.0107 \times L^{2.9574}$ & I & $12.3-43.7$ & $\mathrm{TL}=1.13 \times \mathrm{FL}-0.342$ & Bal et al., 2015 \\
\hline$W=0.0103 \times L^{2.97}$ & I & $16.5-35.3$ & $\mathrm{TL}=1.1348 \times \mathrm{FL}-0.8184$ & Present study \\
\hline
\end{tabular}

L-W: Total length-total weight relationships. GT: Growth types (I: Isometry, -A: Negative allometry). LR: Sampled length range (cm, TL). L-L: Total length-fork length relationships.

In addition, considering that equations for total length-fork length, total length-head girth and total length-maximum girth would not suffice to draw meaningful conclusions without the weight data of the species, length-weight relationship for the sample was also determined. Although the length-weight relationship determined in this study was similar to the findings of Bal et al. (2015), it completely differed from the findings of Erkoyuncu et al. (1994), Kalaycl et al. (2007) and Bök et al. (2011). The reason for finding negative allometric growth may be that the samples consisted of individuals of smaller sizes (Table 1). Such a result might be obtained if the datasets used for length-weight relationship calculations consist of juveniles that have not reached their mature body shape (Safran, 1992) or consist of old individuals that have lost their body shape due to fat deposition (Froese, 2006), or include an insufficient sample size of individuals with a very narrow length (Illkyaz et al., 2010).

The determination coefficients of the relationships between the total length-head girth and the total length-maximum girth revealed strong relationships between these parameters. These parameters directly affect the accuracy of the results obtained from the theoretical catch probability that forms the method of this study. Therefore, these strong relationships were considered to positively affect the results. In addition, steepness and width of the selectivity curves that were plotted with the model are closely associated with the morphology of species. Curves of fusiform fish species are narrow and steep, whereas curves of compressiform species are broad and flat (Hovgård and Lassen, 2000). This is also directly associated with the catch rate at optimum catch length calculated for the mesh size. In this study, the equation for mesh size lengthcatch rate generated a characteristic bell-curve suited to the morphology of the species.

van der Elst and Adkin (1991) reported that the length at first maturity for male individuals of the species inhabiting the Natal (South Africa) region was $24 \mathrm{~cm}$, whereas the length at first maturity for female individuals was $25 \mathrm{~cm}$ fork length. Kailola et al. (1993) determined this parameter as $30 \mathrm{~cm}$ total length at 2 years of age for eastern coasts of Australia. Salerno et al. (2001) reported that the length at first maturity for male individuals of the species inhabiting the coasts of the USA was $33.9 \mathrm{~cm}$, whereas the length at first maturity for female individuals was $33.4 \mathrm{~cm}$ fork length. It is expected for this parameter to differ between stocks from different environments and the established length value for the stock in Turkey is one of the lowest among the values established for different geographical conditions. The legal catch length for the species should be supported by scientific findings and indicate mature individuals that have completed their first reproductive cycle. However, the legal catch length implementation in Turkey is considerably below the required length.

In this study, due to the two different catch lengths for bluefish fishing obtained by a legal study and a scientific study, two different catch lengths were used in the calculations for bluefish fishing. By using the mesh size-catch rate equation given in this study, the catch rate of the desired mesh size for any length group can be calculated. Considering the legal catch length, the use of gillnets with a $55 \mathrm{~mm}$ stretched mesh size is deemed appropriate, whereas considering the scientific findings, the use of gillnets with an $85 \mathrm{~mm}$ stretched mesh size is appropriate. The optimum catch length of the gillnet that allows for fishing above the legal length is notably below the scientifically approved length at first maturity and even the largest fish length that can be captured with this length is below the scientific length (Figure 2). Since different names are used for different sizes in Turkey, individuals at $25 \mathrm{~cm}$ or above are called bluefish, however the size that the current legal regulation allows for fishing is "çinekop" (the name of the bluefish with a length between 10 and $20 \mathrm{~cm} \mathrm{TL}$ ). In other words, the fishing length allowed in Turkey is considerably below the fishing length that should be legally implemented for sustainable fishery. Gillnets with an $85 \mathrm{~mm}$ stretched mesh should be used to catch bluefish at acceptable sizes; that is, $28.0 \mathrm{~cm}$ total length or above.

Although direct estimation methods also allow for estimating gillnet selectivity parameters by using morphometric 
measurements of many fish species (Sechin, 1969; Kawamura, 1972) or fishing individuals whose length-frequency information is known (Illkyaz, 2005), indirect estimation methods are mostly preferred for determining these parameters (Hovgård and Lassen, 2000). The direct estimation model ignores coincidentally captured individuals that were caught on other body parts. However, this method is suited to the bluefish with a morphology that allows for gilled and wedged because there are no extremities on the body. In addition, the direct estimation model does not consider whether or not the length groups suited to capture are in the fishing area. In practical environments, the lack of the length size classes can affect the result to a limited extent. On the other hand, Özekinci (2005) showed the similarity of direct and indirect selectivity estimation results.

In Turkey, by using indirect methods, Sümer et al. (2010) studied the selectivity of 40 and $44 \mathrm{~mm}$ monofilament and multifilament gillnets, while Acarlı et al. (2013) studied the

\section{REFERENCES}

Acarll, D., Ayaz, A., Özekinci, U. \& Öztekin, A., 2013. Gillnet selectivity for bluefish (Pomatamus saltatrix, L. 1766) in Çanakkale Strait, Turkey. Turkish Journal of Fisheries and Aquatic Sciences, 13: 349-353. doi: 10.4194/1303-2712-v13_2_17

Anonymous, 2016. Fisheries regulation for marine and fresh waters for commercial fishery, 2016-2020 fishing period No: 4/1. Ministry of Food, Agriculture and Livestock of Turkey, Protect and Control General Office, Ankara, Turkey.

Bal, H., Yanık, T. \& Türker, D., 2015. Length-weight and length-length relationships of the bluefish Pomatomus saltarix (Linnaeus. 1766) population in the south Marmara Sea of Turkey. Alinteri Journal of Agricultural Sciences, 29 (B), 26-33.

Bok, T. D., Gokturk, D., Kahraman, A. E., Alicli, T. Z., Acun, T. \& Ates, C., 2011 Length-Weight Relationships of 34 Fish Species from the Sea of Marmara Turkey. Journal of Animal and Veterinary Advances, 10 (23), 3037-3042.

Ceyhan, T., Akyol, O., Ayaz, A. \& Juanes, F., 2007. Age, growth, and reproductive season of bluefish (Pomatomus saltatrix) in the Marmara region, Turkey. ICES Journal of Marine Science, 64: 531-536. doi: 10.1093/icesjms/fsm026

Deveciyan, K., 1915. Fish and Fisheries. Düyun-i Umumiye-i Osmaniye Varidat-ı Muhassasa İdare-i Merkezi Matbaası, İstanbul, Turkey, 24-28.

Erkoyuncu, I.., Erdem, M., Samsun, O, Özdamar, E. \& Kaya, Y., 1994. A research on the determination of meat yields, chemical composition and weight- length relationship of some fish species caught in the Black Sea. Istanbul University Journal of Fisheries \& Aquatic Sciences, 8(1-2), 181 191.

FAO, 2016. Food and Agriculture - FishStatJ - software for fishery statistical time series. http://www.fao.org/fishery/statistics/software/fishstatj/en, (11/ 2016).

Froese, R. \& Pauly, D., 2016. FishBase. World Wide Web electronic publication, http://www.fishbase.org, version (06/2016).

Froese, R., 2006. Cube law, condition factor and weight-length relationships: history, meta-analysis and recommendations. Journal of Applied Ichthyology, 22, 241-253. doi: 10.1111/j.1439-0426.2006.00805.x

Haimovici, M. \& Krug, L. C., 1996. Life history and fishery of the enchova Pomatomus saltatrix in southern Brazil. Marine and Freshwater Research, 47, 357-363. doi: 10.1071/MF9960357

Hoşsucu, H., 2000. Fisheries III (Fishing methods). Ege University, Faculty of Fisheries, Publication No 59, Bornova/izmir, Turkey. selectivity of 44, 46, 50 and $56 \mathrm{~mm}$ multifilament gillnets. In the studies conducted in other geographical regions, Trent and Pristas (1977) studied gillnets with a mesh size of at least 63 $\mathrm{mm}$ in the St. Andrew Bay in Florida, USA, while Lucena et al. (2000) studied a $90 \mathrm{~mm}$ mesh size in the southern coasts of Brazil. Compared with the sizes used in these studies, considerably smaller mesh sizes have been used in the studies from Turkey. The reason for choosing smaller mesh sizes in Turkey is commercial fishers' effort to catch smaller individuals, the lack of legal repercussions and the researchers' interest in determining the catch performance of these mesh sizes used in commercial fishing.

In this study, theoretical catch rate of gillnet was determined by utilizing the morphological structure of bluefish, and its relationship with the legal length and length at first maturity in Turkey. In addition, findings on length-length and length-weight of the species were presented.

Hovgård, H. \& Lassen, H., 2000. Manual on estimation of selectivity for gillnet and longline gears in abundance surveys. FAO Fisheries Technical Paper No: 397, Rome, 84P.

İlkyaz, A. T., 2005. Determination of Gillnet Size-Selectivity by the Direct Estimation Method. PhD Thesis Supervisor: Prof. Dr. H. Tuncay Kınacıgil, Ege University Institute of Science, Bornova, İzmir, Turkey, 131P.

İlkyaz, A. T., Metin, G., Soykan, O. \& Kınacıgil, H. T., 2010. Growth and Reproduction of Large-Scaled Gurnard (Lepidotrigla cavillone Lacepède, 1801) (Triglidae) in the Central Aegean Sea, Eastern Mediterranean. Turkish Journal of Zoology, 34(4), 471-478.

Kailola, P. J., Williams, M. J., Stewart, P. C., Reichelt, R. E., McNee, A. \& Grieve, C., 1993. Australian Fisheries Resources. Bureau of Resource Sciences, Canberra, Australia, 422P.

Kalaycı, F., Samsun, N., Bilgin, B. \& Samsun, O., 2007. Length-Weight Relationship of 10 Fish Species Caught by Bottom Trawl and Midwater Trawl from the Middle Black Sea, Turkey. Turkish Journal of Fisheries and Aquatic Sciences, 7, 33-36.

Kawamura, G., 1972. Gillnet mesh selectivity curve developed from length-girth relationship. Bulletin of the Japanese Society for the Science of Fish, 38 1119-1127. doi: 10.2331/suisan.38.1119

Lucena, F. M., O'Brien, C.M. \& Reis, E.G., 2000. The effect of fish morphology and behaviour on the efficiency of gill nets, their selectivity and by-catch: two examples from southern Brazil. ICES Efficiency, Selectivity and Impacts of Passive Fishing Gears, CM 2000/J:11.

Özekinci, U, 2005. Determination of the Selectivity of Monofilament Gillnets Used for Catching the Annular Sea Bream (Diplodus annularis L., 1758) by Length-Girth Relationships in Izmir Bay (Aegean Sea). Turkish Journal of Veterinary and Animal Sciences, 29, 375-380.

Reis, E. G. \& Pawson, M. G., 1999. Fish morphology and estimating selectivity by gillnets. Fisheries Research, 39, 263-273. doi: 10.1016/S0165-7836(98)00199-4

Ricker, W. E., 1973. Linear regressions in fishery research. Journal of the Fisheries Research Board of Canada, 30, 409-434. doi: 10.1139/f73-072

Safran, P., 1992. Theoretical analysis of the weight-length relationship in fish juveniles. Marine Biology, 112, 545-551. doi: 10.1007/BF00346171

Salerno, D.J., Burnett, J., \& Ibara, R.M., 2001. Age, growth, maturity, and spatial distribution of Bluefish, Pomatomus saltatrix (Linnaeus), off the Northeast Coast of the United States, 1985-96. Journal of Northwest Atlantic Fishery Science, 29, 31-39. doi: 10.2960/J.v29.a3 
Sechin, Y. T., 1969. A mathematical model for the selection curve of a gillnet. Rybnoe Khoziaistvo, 45 (9), 56-58.

Sümer, Ç., Özdemir, S. \& Erdem, Y., 2010. Determination of Selectivity Monoflament and Multiflament Gillnets with Different Mesh Size for bluefish (Pomatomus saltatrix L., 1766). Ege University Journal of Fisheries \& Aquatic Sciences, 3, 121-124.

Trent, L. \& Pristas, P. J., 1977. Selectivity of gill nets on estuarine and coastal fishes from St. Andrew Bay, Florida. Fishery Bulletin, 75, 185-198.

Türgan, G., 1959. About biology of Pomatomus saltatrix L. (Bluefish). Hidrobiology Magazine, 5, 144-180. van der Elst, R., 1976. The biology of the Elf, Pomatomus saltatrix (Linnaeus), in the coastal waters of Natal. Game fish of the East Coast of South Africa I. Oceanographic Research Institute, Investigation Report No: 4-4, 1-59.

van der Elst, R.P. \& Adkin, F., 1991. Marine linefish: Priority species and research objectives in southern Africa. Oceanographic Research Institute, Special publication No: 1, 132p.

Whitehead, P. J. P., Mauchot, M. L., Hureau, J. C., Nielsen, J. \& Tortonese, E., 1986. Fish of the North-eastern Atlantic and the Mediterranean. Vol. II: UNESCO.

Wilk, S. J., 1977. Biological and fisheries data on Bluefish, Pomatomus saltatrix (Linnaeus). National Marine Fisheries Service, Northeast Fisheries Center, Sandy Hook Laboratory Technical Series Reports 11, 56p. 